\title{
The Influence of Organizational Learning Capability and Organizational Creativity on Organizational Innovation
}

\author{
Nabila Dwi Hilmiyanti ${ }^{\mathrm{a}, *}$, Retno Kusumastuti ${ }^{\mathrm{a}}$ \\ ${ }^{a}$ Departemen Ilmu Administrasi Niaga, Universitas Indonesia, Kampus UI, Depok, Jawa Barat, Indonesia
}

\begin{abstract}
Technology changes make the organization forced to be flexible and quickly adapt to the fickle innovation and environment. Learning and creativity are the things that can support the realization of innovation. This study aims to determine the influences of organizational learning capability and organizational creativity on organizational innovation at PT XYZ through the individual perception. This research uses quantitative methods with data collection through surveys distributed by questionnaire and uses total sampling with 101 employees. To find out the relationship between variables, this study uses multiple regression analysis techniques. The results of this study indicate that there is a relationship between organizational learning capability and organizational creativity on organizational innovation at PT XYZ.
\end{abstract}

Keywords: organizational creativity, organizational innovation, organizational learning capability

\section{INTRODUCTION}

Various researches stated that an organization should have sustainable innovation to compete in a competitive environment. Innovation is the creation and exploitation of new ideas. According to Luecke (2003), innovation is a general understanding of a new idea or method. Therefore, innovation is very important for an organization, especially for organizations involving production, which is moved by technology and endure the high risk of its technological field (Karagozoglu and Brown, 1993).

The changing of fast and continuous technology, business environment, and various business models make the organization forced to be flexible and quickly adapt to the fickle innovation and environment. Innovation is considered as an individual and group learning process, which tends to find a new method to solve the problems. The creation of innovation depends on the organizational learning capability through the new knowledge developed, distributed, and used (Alegre and Chiva, 2008). McKee (1992) stated that directing the organization into learning can encourage the effectiveness and efficiency of innovation in the organization. Besides, through the learning process, the beginning of the innovation creation is creativity (Sarooghi et al., 2015).

\footnotetext{
${ }^{*}$ Author in correspondence,

Email address: nabiladh0106@gmail.com (Nabila Dwi Hilmiyanti)
}

ISSN: 2549-3221 (Print) 2549-323X (Online)

DOI: $10.26487 /$ hebr.v4i3.2542
Creativity collaborated with innovation will support the survival of the organization (Chaubey and Sahoo, 2019). Anderson et al. (2014) defined the creativity and innovation in the organization as process, result, and product from the effort for developing and introducing new methods, which are better in doing something. A creative organization not only can identify the opportunity to create a new product or potency, in the use of the equipment, or the existing method in a new way but also come with a creative solution against the problems, also throwing the ideas to other people and implementing the new ideas (Oldham and Cummings, 1996). Woodman et al. (1993) defined organizational creativity as creating a product, service, idea, procedure, or a valuable new process for individuals working together in the complex social system.

The presence of a startup in Indonesia should offer something new, which is not available yet in Indonesia. One of the startup fields is the fintech field, which is still rarely found, especially crowdfunding. Crowdfunding is a service for collecting funds from the community to finance a particular project. When talking about the crowdfunding site in Indonesia, the name of PT XYZ always occurs as the top-of-mind. As the first company to apply the crowdfunding concept in Indonesia, PT XYZ has got attention as the number one platform of crowdfunding in Indonesia. PT XYZ is one of the trusted fundraiser websites, established in 2013. PT XYZ is focused on humanitarian missions offering fundraising programs and donations online. Seeing the technology changes quickly, PT XYZ should have an innovation to adjust the transformation and condition 
that happened. The innovation should be conducted because, in its business process, PT XYZ is very dependent on technology. Besides, the innovation needs to be conducted by PT XYZ to always dominating the market and more improving the donors' trust for always donating. PT XYZ has conducted some innovations, and it could see from the social media site of PT XYZ.

The innovations are giving the choices of payment methods (virtual account, bank transfer, GoPay), providing donation platforms in e-commerce such as GoJek, Shopee, and Tokopedia, providing free food-box in several hospitals, and providing a new product. For the internal company itself, several innovations are conducted that are on-boarding for a new employee and changing the manual work into the specific application, especially in the administrative and financial field.

In an attempt to increase employee knowledge, PT XYZ facilitates the learning process for the employee. Some learning forms applied by PT XYZ are the weekly stand-up, following several seminars, facilitating training programs for the employee, providing English class, and facilitating books that could be borrowed related to the employee expert field. This learning process supports the creation of a creative mindset for the employees. Some of the employees' creativity of PT XYZ successfully implemented is the culture of giving something at birthdays, getting closer to donation addressee with conducting campaign visits every week, and doing a partnership with an influencer, athlete, doctor, or external parties to support the fundraising campaign. Thus, the donation could be collected quickly. PT XYZ also has a YouTube channel with creative video content to increase branding, which has a positive meaning.

Seeing the learning and creativity process of PT XYZ, the researcher attempts to fin the impact of learning capability and creativity towards innovation in PT XYZ with the problem (1) How are the influences of organizational learning capability towards organizational innovation of PT XYZ, (2) How are the influences of organizational creativity towards organizational innovation of PT XYZ, (3) How are the influences of organizational learning capability and organizational creativity towards organizational innovation of PT XYZ.

\section{LITERATURE REVIEW}

\subsection{Organizational Innovation}

Innovation has been defined as the successful implementation of creative ideas in an organization (Amabile et al., 2004). Innovation is very important for an organization involved in product production moved by technology, which takes a high risk of technological obsolescence (Karagozoglu and Brown, 1993) with staked continuity because the intensity of competition has marked the environment, the dynamic of technology and market (Kessler and Chakrabarti, 1996). To create new economic value in a fluctuating environment, the existence of access to much information, the ability, and relevant resources is the precondition for transforming from an intention for innovation. Thus, innovation standards at the organization level could be seen from the smallest to the largest. OECD defined organizational innovation as applying the new organizational method in organizational business practice, an organization at the workplace, or an external relationship.

Some features distinguished between organizational innovation and organizational changes that apply the organizational method with the result from a strategic management decision, where this method has never been used before (OECD and of the European Communities, 2005). Specifically, it assumed that organizational innovation in a business practice involves applying the new method to manage routine and procedure, such as building the best practice databases, increasing worker retention, or introducing management systems. Innovation in an organization at the workplace involves applying a new method to distribute the responsibility and making decisions between the employee for work distribution, and new concept for activities arrangement. In this study, the researcher uses the theory by Damanpour and Gopalakrishnan (2001), Aiken and Hage (1971), Zaltman and Holbeck (1973), Zammuto and O'Connor (1992), Oerlemans et al. (2001) with the dimensions of variable measurements are utilized/execute new ideas, utilize/ execute new behaviors, utilize/execute new products, utilize/ execute new services, utilize/execute new technology, and utilize/execute new administrative practices.

Table 1: Organizational Innovation

\begin{tabular}{ll}
\hline Dimension & Indicator \\
\hline $\begin{array}{l}\text { Execute New Be- } \\
\text { haviours }\end{array}$ & $\begin{array}{l}\text { Implementing new behaviors for or- } \\
\text { ganizational development }\end{array}$ \\
\hline $\begin{array}{l}\text { Execute New } \\
\text { Products }\end{array}$ & $\begin{array}{l}\text { Realizing new product for organiza- } \\
\text { tion development }\end{array}$ \\
\hline $\begin{array}{l}\text { Execute New } \\
\text { Services }\end{array}$ & $\begin{array}{l}\text { Using the newest service system for } \\
\text { organizational development }\end{array}$ \\
\hline $\begin{array}{l}\text { Execute New } \\
\text { Technology }\end{array}$ & $\begin{array}{l}\text { Using the newest technology for or- } \\
\text { ganizational development }\end{array}$ \\
\hline $\begin{array}{l}\text { Execute New Ad- } \\
\text { ministration Sys- } \\
\text { tem }\end{array}$ & $\begin{array}{l}\text { Implementing the newest administra- } \\
\text { tion system for organizational devel- } \\
\text { opment }\end{array}$ \\
\hline
\end{tabular}

Sources: Damanpour and Gopalakrishnan (2001); Oerlemans et al. (2001), Zaltman and Holbeck (1973), Zammuto and O'Connor (1992), and Aiken and Hage (1971)

\subsection{Organizational Learning Capability}

Organizational learning is seen as a dynamic process based on knowledge, which moves between various activity levels, starting from the individual into the group level, then into the organizational level and back again (Huber, 1991). This process started from acquiring individual knowledge that developed with the exchange and knowledge integration until it created the collection of collective knowledge (Hedberg, 1981), which is embedded in the organizational and cultural process. Organizational learning capability as the source of competitive 
advantage and the key to organizational success in the future has become a subject in some researches. The organizational learning process is aimed at the enhancement of organizational performance. If a company is more responsive to the organizational learning capability towards the environment change and taking action appropriately, it will increase the competitive advantage. Therefore, organizational learning capability will positively influence company performance.

According to Glinow (1999), organizational learning capability is based on company capability in (1) generating ideas, (2) generalizing those ideas, and (3) identifying learning disabilities. Then, the organizational learning capability is called The Three Building Blocks. The first dimension is generating ideas, which refers to the characters that are obtaining, finding, creating, and ideas source. The second dimension is generalizing those ideas that involve various ideas beyond borders in an organization. The learning process will happen when the ideas transfer from time to time, space, and organizational hierarchy. The third dimension is identifying learning disabilities, which can cause problems in the company, causing the failure to create or generalize an idea. In this study, in the variable of Organizational Learning Capability, the dimensions in variable measurement are Discovery Capability, Invention Capability, Implementation Capability, and Diffusion Capability.

Table 2: Organizational Learning Capability

\begin{tabular}{ll}
\hline Dimension & Indicator \\
\hline $\begin{array}{l}\text { Discovery Capa- } \\
\text { bility }\end{array}$ & $\begin{array}{l}\text { Finding the differences between ex- } \\
\text { pectation and reality }\end{array}$ \\
\hline $\begin{array}{l}\text { Invention Capa- } \\
\text { bility }\end{array}$ & $\begin{array}{l}\text { Finding the solution to control the } \\
\text { differences happen }\end{array}$ \\
\hline $\begin{array}{l}\text { Implementation } \\
\text { Capability }\end{array}$ & $\begin{array}{l}\text { Implementing the solution has been } \\
\text { found to control the differences hap- } \\
\text { pen }\end{array}$ \\
\hline $\begin{array}{l}\text { Diffusion Capa- } \\
\text { bility }\end{array}$ & $\begin{array}{l}\text { Applying the solution for every new } \\
\text { situation in controlling the differ- } \\
\text { ences happen }\end{array}$ \\
\hline
\end{tabular}

Sources: Glinow (1999)

\subsection{Organizational Creativity}

Creativity could be interpreted as the generating of new ideas by approaching the problems or practicing innovatively and imaginatively. The creativity related to innovation is collecting new ideas and changing them into market offers (Norman M. Scarborough, 2010). Based on Amabile (1996), creativity is the production of new ideas (novel) and is useful in all domains. Woodman et al. (1993) stated that creativity creates a valuable and useful product, service, idea, procedure, and process for individuals who collaborate in a complex social system. Those three experts also stated that innovation through creativity is an important factor in reaching success and competitive organizational excellence.
Woodman et al. (1993) defined organization creativity as creating a product, service, idea, procedure, or a valuable new process, useful for individuals who work together in the complex social system (Stundgren, 2007). Jacob (1998) stated that organizational creativity is more than a group of creative individuals (Stundgren, 2007). The factor influencing creativity could come from organizational contextual factors and individual factors form. From the organizational contextual aspect, Amabile (1996) stated that factors of work environment perception in creating the creativity are influenced by organizational motivation, source and management practitioner, impulse against creativity, autonomy or freedom, and work pressure, which are factors that encourage the creation of creativity.

Creativity is an instrument for reaching competitive excellence, which is sustainable in an organization (Shalley, 1995). A creative organization not only can identify the opportunity to create a new product, the potency of using the equipment, or the existing method in a new way but also come with a creative solution towards the problems and throw the ideas to other people, then implement the new ideas (Oldham and Cummings, 1996).

Creative attitude producing output (new product, service, idea, procedure, and process) for all systems comes from a group of individual mosaic, group, and organizational characteristics, the behavior happens in the situational influence that exists at every organizational level. Individual involvement in the creative process creates a higher tendency in producing something creative. Creativity is a result of a process that covers problem identification, information achievement, and idea creation (Gilson and Shalley, 2004; Mumford 2000; in Henker et al. (2014)).

Carmeli (2013) argued that the capacity for problem-solving creatively is not something that refers to the process, but more to the cognitive style that is capacity and ability, which is explored and improved. Individuals could identify, construct, find and explore information, create ideas and evaluate them, choose them, and then implement them. Problem-solving creatively is the point of the creative process related to the levels mentioned. In this study, in organizational creativity variable, the researcher uses the theory by (1989); Harrington (1990); Woodman et al. (1993), and the dimension used are the presence of new/creative processes, the presence of new/creative ideas, the presence of new/creative persons, and the presence of new/creative procedures.

The analysis model in this study will give an overview of how the relationship between the variables. The analysis model used in this study describes a relationship between an independent variable and a dependent variable. The independent variable will be studied organizational learning capability and organizational creativity, while the dependent variable is organizational innovation. Based on the theory delivered, could be described as the formula of the analysis model scheme as follows.

$$
Y=a+b X_{1}+b X_{2}
$$

Where: $\mathrm{Y}=$ Organizational Innovation $; X_{1}=$ Organiza- 
Table 3: Reliability Test

\begin{tabular}{ll}
\hline Dimension & Indicator \\
\hline $\begin{array}{l}\text { Create New Pro- } \\
\text { cesses }\end{array}$ & $\begin{array}{l}\text { Creating new elements to organiza- } \\
\text { tional development }\end{array}$ \\
\hline Create New Ideas & $\begin{array}{l}\text { Producing new ideas for organiza- } \\
\text { tional development }\end{array}$ \\
\hline Create Creative & $\begin{array}{l}\text { Generating creativity spirit of co- } \\
\text { workers }\end{array}$ \\
\hline $\begin{array}{l}\text { Create Nens } \\
\text { Metode }\end{array}$ & $\begin{array}{l}\text { Creating a new method or procedure } \\
\text { for organizational development }\end{array}$ \\
\hline $\begin{array}{l}\text { Sources: Harrington (1990), Woodman et al } \text { (1993), } \\
\text { Karagozoglu and Brown (1993) }\end{array}$
\end{tabular}

tional Learning Capability $; X_{2}=$ Organizational Creativity ; a : Constant; $\mathrm{b}:$ Regression coefficient.

The previous study conducted by Sutanto (2017) showed that organizational learning capability and organizational creativity influence organizational i nnovation. The higher innovation achieved by the organization, the learning, and change performed by the organization would be better. Manifesting the innovation in a company needs high and effective organizational learning capability. Creating innovation in an organization needs creative ideas owned by an individual or group in it. The origin of self-innovation creation is creativity so that selfinnovation is never formed without thought and creative ideas. Based on the explanation above, the hypotheses of this study can be defined as follows:

$H_{o .1}$ : Organizational Learning Capability does not influence Organizational Innovation

$H_{a .1}$ : Organizational Learning Capability influence Organizational Innovation

$H_{o .2}$ : Organizational Creativity do not influence Organizational Innovation

$H_{a .2}$ : Organizational Creativity influence Organizational Innovation

$H_{o .3}$ : Organizational Learning Capability and Organizational Creativity simultaneously do not influence Organizational Innovation

$H_{a .3}$ : Organizational Learning Capability and Organizational Creativity simultaneously influence Organizational Innovation

\section{METHODS}

This study uses a quantitative method with the instrument of data collection used is a survey through questionnaires. According to Neuman (2014), the survey is a data collection technique arranging questions, then submitted to the respondent as a sample of the population through a questionnaire. The sampling collection technique uses total sampling, where the number of population and sample are the same (Neuman, 2014). In this study, the questionnaires are distributed using a closedended question, in which the answers use a Likert scale. The
Likert scale consists of statements to deliver both happy and unhappy actions related to the research object studied (Cooper and Schindler, 2014).

To measure the respondent's answer, the researcher uses 1 to 5, which is strongly disagree until strongly agree. Questionnaires are shared online through Type-form to the 284 employees of PT XYZ, and the questionnaires returned are 101 questionnaires. To avoid bias and measure the validity of the instrument used, the researcher conducted the validity and reliability test. A validity test in this research using $r$ calculation. If the $r-$ value calculated is positive and $>\mathrm{r}$ critical is 0.30 , then the data are considered valid. If the r-value calculated is negative and $<$ 0.30 , then the data are considered not valid. For the test reliability, the researcher uses the Alpha Cronbach method, where this method stated that if the coefficient gets higher, then the instrument in the measurement will get a better result.

The basic decision making as follows:

- If Alpha Cronbach is positive and $r$ Alpha is $>0.60$, then the variable is considered reliable.

- If Alpha Cronbach is negative and $r$ Alpha is $<0.60$, then the variable is considered not reliable.

Descriptive-statistic analysis in this study is divided into two parts. There is descriptive-statistic analysis to describe the respondent characteristic and to describe the tendency of the respondent answer in the research variables. Respondent characteristic in this research is the employees' personal information such as name, age, gender, division, length of work, etc. The second point is questions related to variables. Mean is used to see the tendency of the respondent's answer. Therefore, in this research, analysis is conducted with mean calculation. Thus, this research can determine the distribution of respondent characteristics and the range position of the respondent answer through the calculation of limit value in every class determined. For inferential analysis, this study uses the analysis technique of multiple regression, where an analysis form is used for two or more independent variables $\left(X_{1}\right)$ and $\left.X_{2}\right)$, then will be conducted a simultaneous test for the dependent variable $(Y)$ (Sekaran, 2000).

\section{FINDING AND ANALYSIS}

\subsection{Validity and Reliability Test}

The result of the pre-test in 30 respondents stated that the research variable used has Cronbach's Alpha value above 0.6. Every variable formers' statement has corrected item-total correlation value above the $\mathrm{r}$ table owned, that is $0.361(\mathrm{n}=30)$. Thus, it could be concluded that all the research variables are reliable and could be used to get a consistent answer from the respondents.

\subsection{Respondents Profile}

From the result of questionnaire distribution in the field study, 101 respondents filled the questionnaire with some criteria. The majority of respondents are females around 20-30years-old and had a long period of work for 0-11 months. 
Table 4: Reliability Test

\begin{tabular}{|c|c|c|c|}
\hline Variable & Reliability & Validity & Description \\
\hline \multirow{5}{*}{$\begin{array}{l}\text { Organizational } \\
\text { Learning } \\
\text { Capability }\end{array}$} & \multirow{5}{*}{0.693} & 0.536 & Reliable \\
\hline & & 0.54 & Reliable \\
\hline & & 0.724 & Reliable \\
\hline & & 0.691 & Reliable \\
\hline & & 0.838 & Reliable \\
\hline \multirow{5}{*}{$\begin{array}{l}\text { Organizatonal } \\
\text { Creativity }\end{array}$} & \multirow{5}{*}{0.785} & 0.72 & Reliable \\
\hline & & 0.654 & Reliable \\
\hline & & 0.852 & Reliable \\
\hline & & 0.754 & Reliable \\
\hline & & 0.706 & Reliable \\
\hline \multirow{8}{*}{$\begin{array}{l}\text { Organizational } \\
\text { Innovation }\end{array}$} & \multirow{8}{*}{0.851} & 0.706 & Reliable \\
\hline & & 0.808 & Reliable \\
\hline & & 0.604 & Reliable \\
\hline & & 0.682 & Reliable \\
\hline & & 0.719 & Reliable \\
\hline & & 0.709 & Reliable \\
\hline & & 0.659 & Reliable \\
\hline & & 0.713 & Reliable \\
\hline
\end{tabular}

\subsection{Descriptive Analysis}

This research is conducted a descriptive analysis to measure the high or low of variable application, which is tested in PT $\mathrm{XYZ}$. The descriptive analysis uses the mean test, and the result as Table 5 .

Table 5: Mean Test

\begin{tabular}{lcc}
\hline Variabel & Mean & Description \\
\hline Organizational Innovation & 4.04 & High \\
$\begin{array}{l}\text { Organizational Learning } \\
\text { Capability }\end{array}$ & 3.79 & High \\
Organizational Creativity & 3.61 & High \\
\hline
\end{tabular}

\section{Hypotheses Test 1}

Based on the result of the descriptive statistical test in the variable of organizational learning capability, organizational creativity, and organizational innovation, it could be found that the application of organizational innovation variable in PT XYZ has the highest mean value with 0.04 . The second high value is organizational learning capability with 3.79 , and the last is organizational creativity with 3.61. These results show that PT $\mathrm{XYZ}$ creates innovation in its organization by applying new methods, using a new system, creating a new product, and implementing new ideas given by the employee. Innovation applying in PT XYZ also involves employee contribution through responsibility and decision-making.
Table 6: Coefficient-Correlation and Coefficient-Determination of Organizational Learning Capability Variable

\begin{tabular}{cccc}
\hline R & R Square & $\begin{array}{c}\text { Adjuster } R \\
\text { Square }\end{array}$ & $\begin{array}{c}\text { Std.Error of } \\
\text { the Estimate }\end{array}$ \\
\hline 0.203 & 0.041 & 0.032 & 3.256 \\
\hline
\end{tabular}

\section{Hypotheses Test 2}

Table 6 shows that the coefficient-correlation value $(\mathrm{R})$ is 0.203 and has a positive value. Based on interpretation from de Vaus (2002), coefficient-correlation value in organizational learning capability variable can be interpreted that there is a low relationship between organizational learning capability and organizational innovation. In this study, the value of $\left(R_{2}\right)=0.41$ means the organizational learning capability variable has a high influence of $4.1 \%$ towards the organizational innovation variable in PT XYZ. The rest is $95.9 \%$ explained by other variables outside the model.

Table 7 shows that the variable $\mathrm{x}$ affects $\mathrm{y}$ significantly by taking into account the p-value which is below 5

Table 8 shows that the coefficient-correlation value $(\mathrm{R})$ is 0.239 and has a positive value. Based on interpretation from de Vaus (2002), coefficient-correlation value in organizational learning capability variables can be interpreted that there is a low relationship between organizational creativity and organizational innovation. In this study, the value of $(\mathrm{R} 2)=0.57$, which means the organizational creativity variable has a high influence of 5.7\% towards the organizational innovation variable in PT XYZ. The rest is $94.3 \%$ explained by other variables outside the model.

From Table 10 can be seen that the coefficient-correlation value is 0.285 and have a positive value. Based on the theory from de Vaus (2002), the value shows the low positive relationship simultaneously between organizational learning capability and organizational creativity towards organizational innovation. Then, it also could be seen in the coefficient determination value, which shows the number of 0.081 or $8.1 \%$. This value means, simultaneously, the independent variable of organizational learning capability and organizational creativity is $8.1 \%$, which can explain against the dependent variable of organizational innovation. The rest is $91.9 \%$ explained by other variables outside the model.

Table 11 shows that p-value of ANOVA test is $1.6 \%$ which is less than 5\% that means $H_{03}$ rejected and $H_{a 3}$ received. It shows that the statement of $\mathrm{Ha} 3$ that is organizational learning capability influences the organizational innovation received.

This study shows an influence simultaneously from the variables of organizational learning capability and organizational creativity towards organizational innovation in PT XYZ. This study also supports the previous study conducted by Sutanto (2017), which shows the influence of organizational learning capability and organizational creativity on organizational innovation. Organizational learning capability has a positive relationship with organizational innovation, although both the relationships are low.

The higher innovation achieved by an organization, the higher 
Table 7: The Result of t-Test in Organizational Learning Capability Variable

\begin{tabular}{|c|c|c|c|c|c|}
\hline \multirow[t]{2}{*}{ Variable } & \multicolumn{2}{|c|}{$\begin{array}{l}\text { Unstandardized } \\
\text { Coefficients }\end{array}$} & \multirow{2}{*}{$\begin{array}{c}\text { Standardized } \\
\text { Coefficients } \\
\text { B }\end{array}$} & \multirow[t]{2}{*}{$\mathbf{t}$} & \multirow[t]{2}{*}{ p-value } \\
\hline & B & Std. Error & & & \\
\hline constant & 26.749 & 2.944 & & 9.086 & 0.000 \\
\hline V1 & 0.313 & 0.152 & 0.203 & 2.065 & 0.042 \\
\hline
\end{tabular}

Table 8: Coefficient-Correlation Value and Coefficient-Determination of Organizational Creativity Variable

\begin{tabular}{crrr}
\hline $\mathbf{R}$ & $\mathbf{R}$ Square & $\begin{array}{l}\text { Adjuster } \\
\text { Square }\end{array}$ & $\begin{array}{l}\text { Std.Error of } \\
\text { the Estimate }\end{array}$ \\
\hline 0.239 & 0.057 & 0.048 & 3.229 \\
\hline
\end{tabular}

learning and changes should be needed by the organization. The high innovation level needs effective learning capability in an organization. However, seeing from the result of the study, it could be known that the learning capability and creativity by individual perceptions in PT XYZ does not have many roles in the innovation occurrence of the organization. Learning capability and creativity in PT XYZ is only limited in the environment among employees, but not maximally contributed to the innovation. Unfortunately, there is a space for PT XYZ to be more innovative with the skill that the employees have. In this case, a leadership role is a must. They should make a comfortable environment for their employees so that they can be braver to express their ideas. Leadership like this will make a positive learning environment and creativity which will be more beneficial for boosting the innovation of the company.

\section{CONCLUSION}

Based on the result of the study conducted and the discussion analysis presented in the previous chapter, it could be concluded that the application of organizational learning capability in PT XYZ influences organizational innovation. The employees of PT XYZ have had the learning capability to resolve the problems in PT XYZ. However, the relationship between the two variables is still relatively weak. Seeing from statistical tests in the application of organizational creativity at PT XYZ also influences the support in the creation of organizational innovation. The employees of PT XYZ have had creative ideas, but not maximally implemented. Thus, the influence of organizational creativity towards organizational innovation in PT $\mathrm{XYZ}$ is still relatively weak. There are simultaneous influences between organizational learning capability and organizational creativity towards organizational innovation in PT XYZ. However, the relationship between the three of them is still relatively weak.

\section{References}

Aiken, M., Hage, J., 1971. The organic organization and innovation. Sociology $5(1), 63-82$

URL: http://www.jstor.org/stable/42851013
Alegre, J., Chiva, R., 2008. Assessing the impact of organizational learning capability on product innovation performance: An empirical test. Technovation $28(6), 315-326$.

URL: https://www.sciencedirect.com/science/article/pii/ S0166497207001320

DOI: https://doi.org/10.1016/j.technovation.2007.09.003

Amabile, T. M., C. R. C.-H. L. J. . H. M., 1996. Assessing the work environment for creativity. Academy of Management Journal 39. DOI: $10.2307 / 256995$

Amabile, T. M., Schatzel, E. A., Moneta, G. B., Kramer, S. J., 2004. Leader behaviors and the work environment for creativity: Perceived leader support. The Leadership Quarterly 15 (1), 5-32.

URL: https://www.sciencedirect.com/science/article/pii/ S1048984303001000

DOI: https://doi.org/10.1016/j.leaqua.2003.12.003

Anderson, N., Potočnik, K., Zhou, J., 2014. Innovation and creativity in organizations: A state-of-the-science review, prospective commentary, and guiding framework. Journal of Management 40 (5), 1297-1333.

URL: https://doi.org/10.1177/0149206314527128 DOI: $10.1177 / 0149206314527128$

Carmeli, A., G. R. . R.-P. R., 2013. Leadership, creative problem-solving capacity, and creative performance: the importance of knowledge sharing. Human Resource Management 52 (1), 95-122. DOI: $10.1002 / \mathrm{hrm} .21514$

Chaubey, A., Sahoo, C., 01 2019. Enhancing organizational innovation in indian automobile industry. International Journal of Innovation Science 11 (1), $82-101$. DOI: $10.1108 /$ IJIS-02-2018-0022

Cooper, D. R., Schindler, P. S., 2014. Business Research Methods, 12th Edición. McGraw-Hill Education.

Damanpour, F., Gopalakrishnan, S., 01 2001. The dynamics of the adoption of product and process innovations in organizations. Journal of Management Studies $38,45-65$. DOI: $10.1111 / 1467-6486.00227$

de Vaus, D., 2002. Analyzing Social Science Data, 1st Edición. SAGE Publications Ltd.

Glinow, A. K. Y. D. U. S. W. N. M. A. V., 1999. Organizational Learning Capability: Generating and Generalizing Ideas with Impact. Oxford University Press.

Harrington, D. M., 1990. The ecology of human creativity: A psychological perspective. in m. a. runco, r. s. albert (eds.). Theories of creativity.

Hedberg, B. L. T., 1981. How organizations learn and unlearn. in handbook of organizational design 1.

Henker, N., Sonnentag, S., Unger, D., 06 2014. Transformational leadership and employee creativity: The mediating role of promotion focus and creative process engagement. Journal of Business and Psychology 30. DOI: $10.1007 / \mathrm{s} 10869-014-9348-7$

Huber, G. P., 1991. Organizational learning: The contributing processes and the literatures. Organization Science 2 (1), 88-115.

URL: https://EconPapers.repec.org/RePEc : inm: ororsc:v:2:y: $1991: i: 1: p: 88-115$

Jacob, N., 1998. Creativity in Organisations. Wheeler Publishing.

Karagozoglu, N., Brown, W. B., 1993. Time-based management of the new product development process. Journal of Product Innovation Management 10 (3), 204-215.

URL: https://www.sciencedirect.com/science/article/pii/ $073767829390026 \mathrm{M}$

DOI: https://doi.org/10.1016/0737-6782 (93) 90026-M

Kessler, E. H., Chakrabarti, A. K., 1996. Innovation speed: A conceptual model of context, antecedents, and outcomes. The Academy of Management Re- 
Table 9: The Result of t-Test in Organizational Creativity Variable

\begin{tabular}{|c|c|c|c|c|c|}
\hline \multirow[t]{2}{*}{ Variable } & \multicolumn{2}{|c|}{$\begin{array}{l}\text { Unstandardized } \\
\text { Coefficients }\end{array}$} & \multirow{2}{*}{$\begin{array}{c}\text { Standardized } \\
\text { Coefficients } \\
\text { B }\end{array}$} & \multirow[t]{2}{*}{$\mathbf{t}$} & \multirow[t]{2}{*}{ p-valu } \\
\hline & B & Std. Error & & & \\
\hline constant & 26.120 & 2.743 & & 9.524 & 0.000 \\
\hline V2 & 0.331 & 0.135 & 0.239 & 2.449 & 0.016 \\
\hline
\end{tabular}

Table 10: Coefficient-Correlation Value and Coefficient-Determination Simultaneously of Organizational Learning Capability Variable and Organizational Creativity

\begin{tabular}{cccc}
\hline R & R Square & $\begin{array}{c}\text { Adjuster R } \\
\text { Square }\end{array}$ & $\begin{array}{c}\text { Std.Error of } \\
\text { the Estimate }\end{array}$ \\
\hline 0.285 & 0.081 & 0.063 & 3.203 \\
\hline
\end{tabular}

view 21 (4), 1143-1191.

URL: http://www.jstor.org/stable/259167

Luecke, R., 2003. Managing creativity and innovation. Boston, Mass. : Harvard Business School Press.

McKee, D., 1992. An organizational learning approach to product innovation. Journal of Product Innovation Management 9 (3), 232-245.

URL: https://www.sciencedirect.com/science/article/pii/ 0737678292900339

DOI: https://doi.org/10.1016/0737-6782(92) 90033-9

Neuman, W., 2014. Social Research Methods: Qualitative and Quantitative Approaches, 8th Edición. Pearson Education, Essex, UK.

Norman M. Scarborough, Douglas L. Wilson, T. Z., 2010. Essentials of entrepreneurship and small business management. Upper Saddle River, N.J. : Pearson/Prentice Hall.

OECD, of the European Communities, S. O., 2005. Oslo Manual: Guidelines for Collecting and Interpreting Innovation Data, 3rd Edition.

URL: https://www.oecd-ilibrary.org/content/publication/ 9789264013100-en

DOI: https://doi.org/https://doi.org/10.1787/9789264013100-en

Oerlemans, L., Meeus, M., Boekema, F., 07 2001. Firm clustering and innovation: Determinants and effects. Papers in Regional Science 80, 337-356. DOI: $10.1007 /$ PL00013637

Oldham, G. R., Cummings, A., 1996. Employee creativity: Personal and con- textual factors at work. The Academy of Management Journal 39 (3), $607-$ 634.

URL: http://www.jstor.org/stable/256657

Sarooghi, H., Libaers, D., Burkemper, A., 2015. Examining the relationship between creativity and innovation: A meta-analysis of organizational, cultural, and environmental factors. Journal of Business Venturing 30 (5), 714-731.

URL: https://www.sciencedirect.com/science/article/pii/ S0883902614001098

DOI: https://doi.org/10.1016/j.jbusvent.2014.12.003

Sekaran, U., 2000. Research methods for business: a skill-building Approach. Singapore: John Wiley Sons, Inc.

Shalley, C. E., 1995. Effects of coaction, expected evaluation, and goal setting on creativity and productivity. The Academy of Management Journal 38 (2), 483-503.

URL: http://www . jstor.org/stable/256689

Stundgren, M., . S. A., 2007. Creativity and the fallacy of misplaced concreteness in new drug de-velopment. a white headian perspective. European Journal of Innovation Management 10 (2).

Sutanto, E. M., 2017. The influence of organizational learning capability and organizational creativity on organizational innovation of universities in east java, indonesia. Asia Pacific Management Review 22 (3), 128-135.

URL: https://www.sciencedirect.com/science/article/pii/ S1029313215201042

DOI: https://doi.org/10.1016/j.apmrv. 2016.11.002

Woodman, R., Sawyer, J., Griffin, R., 04 1993. Toward a theory of organizational creativity. Academy of Management Review 18, 293-321. DOI: 10.5465/AMR. 1993.3997517

Zaltman, G., D. R., Holbeck, J., 1973. Innovation and Organizations. New York Wiley.

Zammuto, R., O’Connor, K., 1992. Business strategy, technology policy and firm performace. Strategic Management Journal 14. 
Table 11: The Result of F Test (ANOVA)

\begin{tabular}{|c|c|c|c|c|c|}
\hline & $\begin{array}{l}\text { Sum of } \\
\text { Squares }\end{array}$ & If & $\begin{array}{l}\text { Mean } \\
\text { Square }\end{array}$ & $\mathrm{F}$ & p-value \\
\hline Regression & 89.032 & 2 & 44.516 & 4.338 & .016 \\
\hline Residual & 1005.601 & 98 & 10.261 & & \\
\hline Total & 1094.634 & 100 & & & \\
\hline
\end{tabular}

